\title{
A Proposal of a Cluster Model Dedicated to the Development of the Water Industry in Morocco
}

\author{
Rajae AMINE \\ PhD \& Professor of Economics at ISGA, Marrakech, Morocco
}

\begin{abstract}
Morocco is dependent on rainfall for its water supplies, and suffers severely from the impact of climate change, which signals a situation of water stress. This scarcity of resources represents a challenge, but also an economic opportunity for companies that can provide solutions for efficiency, optimization and reuse. Analysis of previous studies and reports from international institutions, ministerial reports and specialized literature, crossed with interviews with professionals in the water sector and our own observations, has led us to propose a model for the creation of a cluster dedicated to the water industry. This article proposes a cluster model adapted to the context of a developing country and to the specificities of the strategic water industries sector. The Cluster $\hat{O}^{1}$ will be dedicated to the development of the water sector in Morocco, particularly an industry with high technological added value, based on innovation, scientific research, promoting technology transfer and enhancing national capacities.
\end{abstract}

Keywords: Water industry; Cluster; Technology transfer; Morocco.

\section{INTRODUCTION}

Survey

Morocco is dependent on rainfall for its water supplies, and suffers severely from the impact of climate change, which signals a situation of water stress. The available water resources are becoming rare and announcing a future scarcity of water resources, which is a challenge that can also be perceived as an opportunity. It is worth noting that, despite the efforts made by the Moroccan expertise which dates back to 1970, with regard to conventional water resources (such as prospecting, planning, development, mobilization, management, irrigation, drinking water supply etc...) as well as non-conventional water resources (for instance; seawater desalination, demineralization of brackish waters, reuse of domestic and industrial wastewater), the national water sector capacities are fragmented, yet they do not reach an industrial development. Likewise, research in water resources field is facing obstacles, although the great efforts made to improve water technologies innovations, nonetheless, they remain individual and insufficient initiatives operating in a disconnected manner amongst complementary technological capacities that leads to a situation of an under-utilization of the national potentialities.

\section{Rational}

Thanks to the exploratory approach that we conducted and through which we have gathered theoretical contributions as well as field research, two major observations have been yielded:

\footnotetext{
${ }^{1}$ Ô sounds like « Eau », which is the French for « water ».
} 
1. The lack or we would rather say the deficiency of coordination and exchange between institutions and water sector stakeholders.

2. Reliance on foreign firms that own the technology, managerial efficiency and the efficiency of procedures.

Therefore, regarding the Moroccan economy context, which has seen the implementation of various types of business agglomeration, including the Integrated Industrial Platforms, the Technopoles and lately, the Clusters experience (Amine, 2017), and in the midst of the water sector's urgent needs, the establishment of a cluster dedicated to the water industry, for which we choose the name Cluster Ô, presents itself as an interesting solution.

Our present concern is to develop an approach for designing the structure of Cluster Ô, so that it can unite all different stakeholders of the water sector in order to initiate an active collaboration and thus concentrate the efforts led at the different levels of the water sector. In the present article, we have tried to design a model as a response to our concern. Such is the gist of the constructivist paradigm behind our research. .

\section{THEORETICAL FRAMEWORK AND METHODOLOGY}

In order to ensure a matching answer to our issue, first of all we would carry out an inquiry on theoretical material such as theories of micro-economy (Porter, 1990, 1997, 2004), macroeconomics (Fujita, 1997 ; Champagne, 2008), international trade (Markusen, 1996), Geographical economics (Weber, 1909 ; Hoover, 1937 ; Raffestin, 1986 ; Krugman, 1993 ; Rosenfield, 1997 ; Moine, 2005), industrial economics (Schumpeter, 1934 ; Marchall, 1980; Ascheim , 2006 ) The relational and socio-cultural approach (Beccatini, 1989; Oldenburg, 1991 ; G. DI Méo, 1998 ; Suire R. \& Vicente J. 2007 ; Torre, 2008 ; Chabalaut, 2010) and the economy of knowledge (Ellul, 1964 ; Eaton J. \& Kortum S., 1999 ; Abrams, 2009 ; Albors, 2012 ; Glachant, 2013 ; M. Dussaux, D. Ménière, Y. \& Dechezleprêtre, A , 2013 ). As well as reports and in-house documents of the National Office of Water and Electricity $2013 \mathrm{a}$ and b, of the Ministry Delegate in charge of Water in 2012 and 2013, The Office Chérifien des Phosphates 2014 (OCP), of GIZ 2009, UNO/ ECA in 2015, FAO in 2001, UNEP-WFP 2009, etc.). Subsequently, we collected data through interviews with the administration in charge of water and Electricity such as the Agency of the Hydraulic Basin, the Moroccan Association of Water and the Professionals of the Sanitation; likewise, we succeeded in data gathering from the department of Water Research and Planning in the Ministry Delegate in charge of Water.

\section{WATER CONTEXT AND WATER SECTOR IN MOROCCO}

Undoubtedly, water resources play a strategic role in the socio-economic development of Morocco. However, the country's overall water situation is said to be remarkably in degradation, irregularities are more obvious, and the situation is rapidly changing over time and in space. Henceforth, a significant increase in the drinking water needs of households, industries, agriculture and tourism is clearly alarming. Under those circumstances, both short-term and structural water shortages are expected to worsen, and according to the National Office of Water \& Electricity (ONEE / Water Branch, 2011) a water crisis is foreseen by 2030.

\section{A. Report on water needs in Morocco}

Given the fact that, the overall situation of short-term and structural water shortages is more likely to deteriorate, the important growth of the population, the continuous increase of human needs due to changes in people's lifestyles, the development of some water-consuming activities (tourism, industry, etc.), environmental degradation and the impact of Climate change make it impossible to adequately match the water needs of the population, irrigation and industry. Consequently, we end up with a negative impact on the economic and social development of the country. 
Moreover, the irrigation-oriented agriculture remains the most water-consuming sector with more than $87 \%$ of the total water uses in Morocco. However, it is one of the strategic economic sectors, contributing to food security and playing a leading role in rural development. However, water is a resource that can be subjected to many hazards and exists in very limited quantities. Not only that, but even the means used to collect water for drinking water supply, for industry or for irrigation (water pumping from rivers, dams, or by pumping of the groundwater) have shown their limitations in terms of low surface water inputs, siltation and eutrophication of dams (Loss of regularized volumes due to siltation of about $75 \mathrm{Mm} 3$ per year) and difficulties in equipment installation in new worksites and overexploitation $(+25 \%)$, which led to the drainage of groundwater under the excessive different effects of drought and intensive pumping.

The demand for drinking water (leaving out irrigation water and water for industrial production) is constantly evolving. The following graph shows the evolution since 2014, as well as the expected changes in drinking water demands.

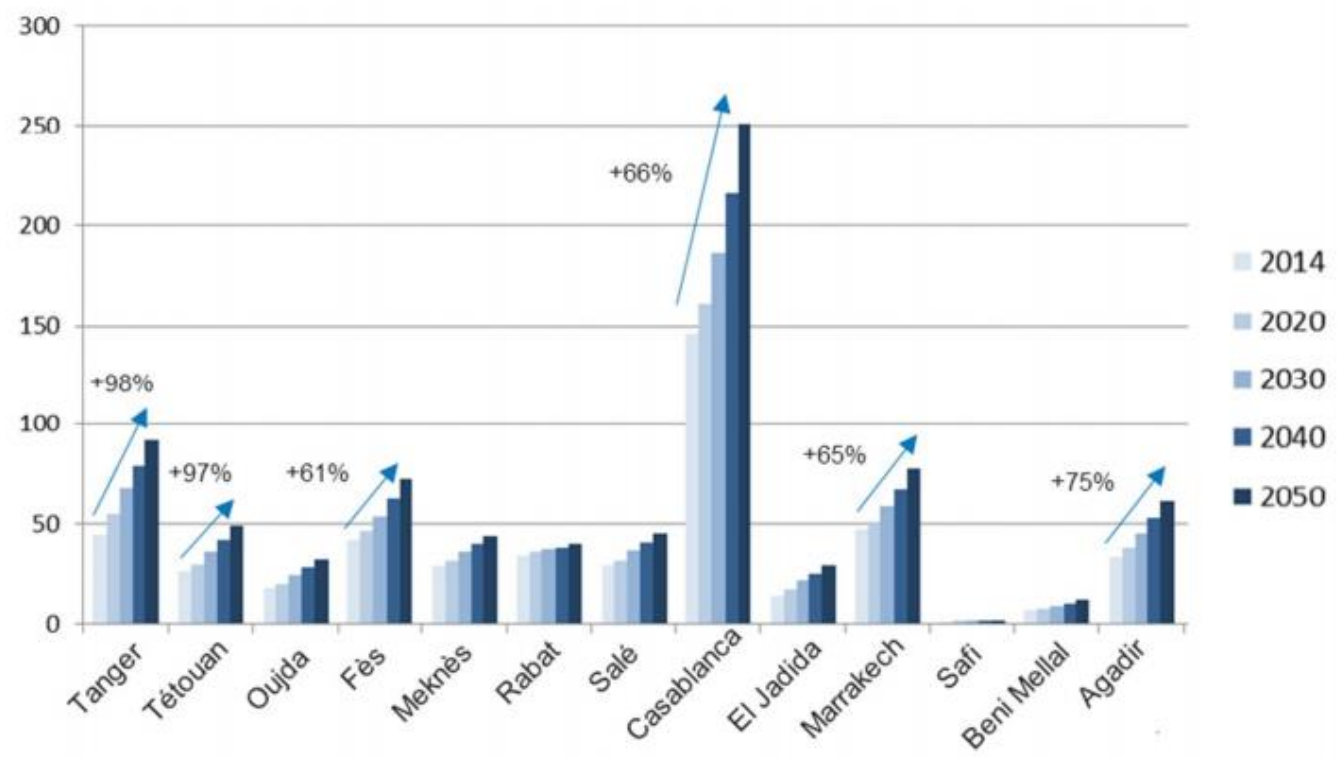

Figure $\mathrm{N}^{\circ} 1$ : Forecast trends in drinking water requirements between 2014-2050 (Liters per capita per day)

Source: International Bank for Reconstruction and Development / World Bank "Management of Water Scarcity in Urban Areas in Morocco "2017

This change in water demand will not be a positive one, starting from 2020, due to a decrease in water potential amounting to $570 \mathrm{~m} 3$ per year for each inhabitant, the majority of the under-ground water will be severely degraded, and most basins will eventually have a deficit by 2030 . From then on, Morocco will be affected by a water shortage and a crisis, a situation that has been already undergone by the kingdom's neighboring countries.

\section{B. Moroccan Water Resources}

Despite the average rainfall of around 140 billion $\mathrm{m} 3$ / year, water resources potential of 22 billion $\mathrm{m} 3$ / year, and water resources, although they are said to be generous if seen from a regional perspective, are nonetheless limited (Due to the geographical location of the country in a semi-arid zone), the available water 
storage remains limited to $730 \mathrm{~m} 3$ per year per inhabitant, which is well below the normal threshold set at 1000m3 per year per inhabitant (National Office of Water and Electricity, 2013).

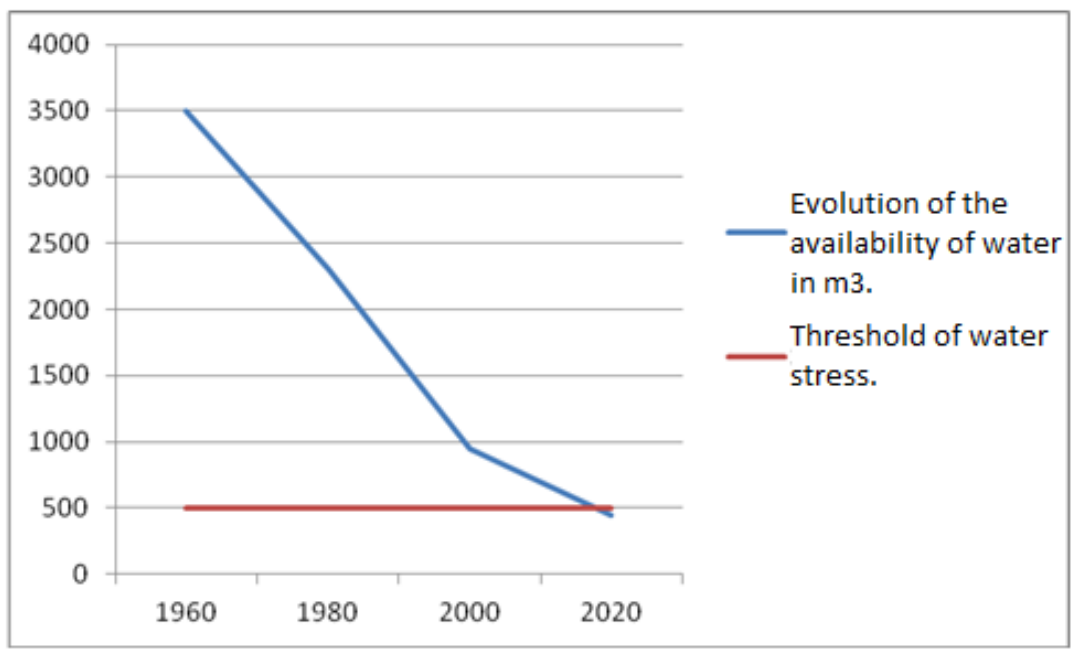

Figure $\mathrm{N}^{\circ}$ 2: Evolution of water availability in $\mathrm{m} 3$ / year / inhabitant in Morocco

Source: Central Regional Equipment Company, "Opportunities in the field of conceded management of seawater desalination plants in Morocco", 2015

The following chart shows the annual changes over the past six decades in the water flows recorded in the national Moroccan territory. A downturn in contributions of $15 \%$ to $20 \%$ has been observed over the past 30 years and will further decrease by $10 \%$ to $15 \%$ by $2020^{2}$.

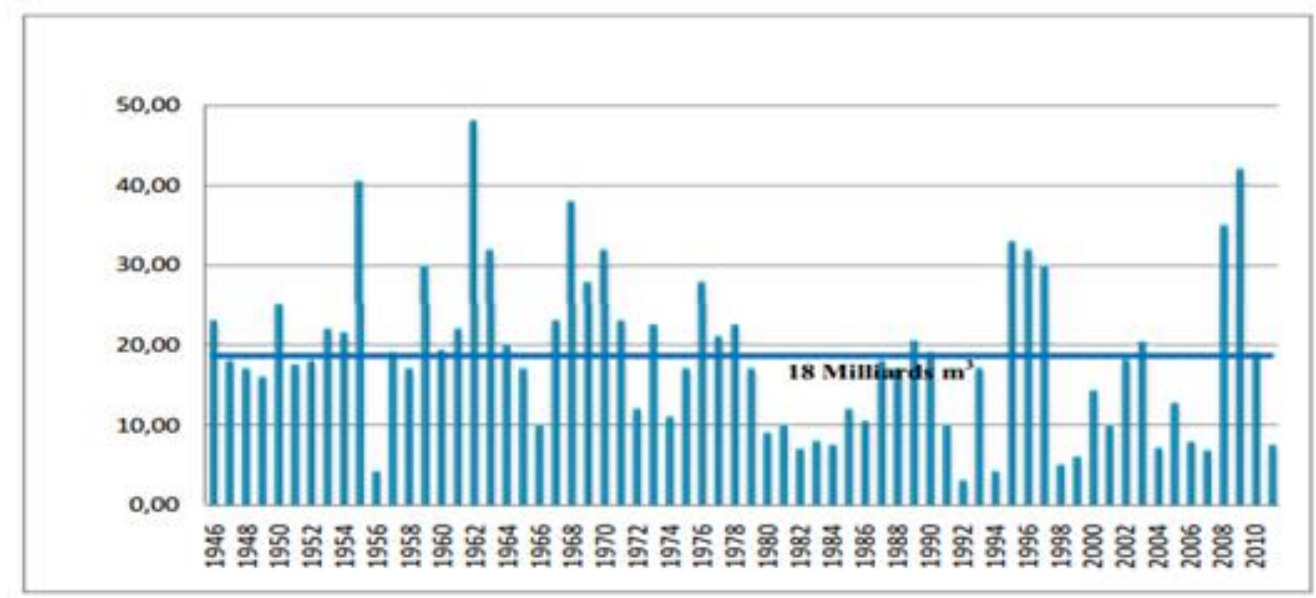

Figure $N^{\circ} 3$ : Evolution of annual flows in Million cubic meters between 1946 and 2011

Source: National Office of Electricity and Drinking Water - Water Branch, "Report on the situation of water resources and the filling of dams during the hydrological year 2011-2012”, 2012

2 From the report "Water sector in Morocco and strategy of the National Office of Electricity and Drinking Water", Planning Directorate, 2013 
For the sake of meeting future challenges, the Economic, Social and Environmental Council (2014) has recommended that an additional annual water mobilization of 6.4 billion $\mathrm{m} 3$ per year must be achieved by 2020 , representing more than $25 \%$ of the annual total resources of the country and more than 6 times the current non-renewable resource withdrawals, detailed as follows:

- $\quad 31 \%$ will be ensured by means of drawing 400 million $\mathrm{m} 3$ per year of water from seawater desalination and demineralization of brackish water;

- $\quad 27 \%$ shall be ensured by following the dam policy;

- $25 \%$ through massive conversion to localized irrigation and sprinkling;

- $11 \%$ through the re-use of purified waste water for industrial, touristic and domestic use;

- Finally, the remaining 6\% would be ensured through improved network yields.

With the aim of meeting the country's needs and availing itself to strengthening its position amidst the African continent; the establishment of a research and federation platform of stakeholders as a cluster devoted to the development of the water industry is an urgent need.

\section{RECOMMENDATIONS FOR THE ESTABLISHMENT OF A WATER INDUSTRIAL DEVELOPMENT CLUSTER IN MOROCCO}

The water sector plays a strategic role in the socio-economic development in Morocco. However, the general context of the country announces an upcoming crisis. Despite the critical situation, it represents an economic opportunity that is embodied in the development of a national water industry. Additionally, researches supporting our reflection were conducted by the Moroccan Department of the Environment jointly with UNDP support for the YES GREEN project, which aimed at pin pointing green employment opportunities has identified four sectors with strong job creation potential, including water and sanitation (UN / ECA in 2015).

An industrial cluster is "a conceptual framework, an empirical construction, and a political tool" (Asheim $\&$ al, in 2006), which enable governments to promote and consolidate the development of targeted sectors. Note that, the establishment of a cluster in a developing country such as Morocco, based on successful models such as, for instance, the German Kompetenznetze3, clusters of the Spanish Basque Country4, or French Pôles de Compétitivité5, while taking into account their social contexts, The public authorities play a major catalytic role through their influence on the business environment, the upgrading of infrastructures and the development of an environment of trust between the various stakeholders.

Being aware that each territory is a unique ecosystem, and that each industry has its own value chain, and that there is no "one size fits all" cluster model, we tried to design a cluster model that is adapted to the

\footnotetext{
3 Fourmond S., «Innovation through networking skills», Kompetenznetze Deutschland initiative, 2010

4 "The Clusters to boost the French industry. The success of "clusters" in the Spanish Basque Country." Press file of the France-Eukasdi Institute, 2005 .

5 “ The survey of the managers of the Pôles de Compétitivité” Evaluation study of the clusters 2012, Bearing Point, Erdyn, Technopolis.
} 
context and to the uniqueness of the water sector requirements in Morocco. Notably, our proposal shall be based on three main aspects: A. the establishment of the cluster; B. monitoring measures; C. evaluation procedure of the cluster's performance.

\section{ESTABLishment OF THE CLUSTER Ô STRUCTURE}

In order to launch the cluster project, it is necessary to sketch a thoughtful plan that would ensure the involvement of different strategic partners in a participatory approach.

The water cluster launching process must be effectively integrated into national strategies to support the water and sanitation sector and the protection of the environment.

\section{a. The cluster problematic:}

From a national perspective, water is a major strategic issue, so the Cluster Ô should be a national cluster to provide appropriate answers to the following problematic:

How to develop the national expertise in the exploitation and development of water resources, and the creation of an ecosystem allowing the cross fertilization of knowledge and the promotion of technology transfers between academics and industrialists, national and international stakeholders, in view of establishing a strong competitive industrial sector, offering green job opportunities, and active in protecting the environment and supporting the export of Moroccan expertise at regional and international level?

This concern is part of a strategic vision, which is the creation of a national hub to consolidate and develop the skills and competitiveness of national companies and empower them to invest in international markets.

\section{b. Relevant Stakeholders:}

The identification of the partners involved in such initiative is a step of a crucial importance in the whole process. Therefore, based on the rational presented in the UNIDO report "Dissemination of the cluster approach in three Maghreb countries" (2013), we will give a brief presentation of the concerned stakeholders constituting the immediate environment of the new cluster:

- Flagship units: Private sector stakeholders are key to the Water sector in Morocco, can be identified in the following sectors:

- Research: Engineering departments;

- Monitoring the compliance with the standards: laboratories;

- Water pipes: manufacturing special pipes and spare parts ${ }^{6}$.

- Electromechanical Equipments ${ }^{7}$ and Works are the technological components varying from electrical, electronic and electromechanical hydraulic equipment that are exclusively imported from German, Spanish, Portuguese, Italian, Chinese and Turkish manufacturers.

\footnotetext{
${ }^{6}$ Special parts are parts made of cast iron and / or galvanized steel, for example: valves, elbows, etc.

${ }^{7}$ Pumps, generators, industrial filters, reverse osmosis, etc.
} 
- Civil engineering: Moroccan companies operating in construction Works of water reservoir, stations, implementation of drilling operations ...etc.

- Upstream unit: the Moroccan companies constituting electrical, electronic and electromechanical equipment's market, having the execution of electrical, electronic and electromechanical Works as an additional activities;

- Downstream Unit: is composed of companies such as authorized suppliers operating under the delegated management of water, sanitation and electricity services;

- Relevant Authorities are the followings:

- Ministry of Industry, Trade, Investment and Digital Economy;

- Ministry of Equipment;

- Ministry of the Interior ${ }^{8}$;

- Ministry of Health;

- Ministry of Economy and Finance;

- Secretary of State to the Minister of Equipment, Transport, Logistics and Water, in charge of water (previously known as the Ministry delegate to the Ministry of Energy, Mines, Water, and Environment Morocco in charge of Water);

- Ministry of Agriculture, Fisheries, Rural Development, Water and Forests (previously known as the Ministry of Agriculture and Fisheries);

- The National Office for Water and Electricity / Water department (ONEP/BE);

- Regional Offices for Agricultural Development.

- Other institutional partners ( referring to the consultative entities in water sector):

- The High Commission for Water, Forests and the Fight against Desertification;

- Regional Environmental Councils (REC);

- County and Provincial Water Commissions;

- The Permanent Commission in charge of Environmental Affairs and Regional Development of the Economic, Social and Environmental Council;

- The High Council for Water and Climate;

- Hydraulic Basins Agencies;

- The Interministerial Water Commission is the entity that has been out of service many years ago.

${ }^{8}$ Equivalent to Ministry of Home Affairs 
- Public Services institutions ( Semi-public bodies, namely inter-communal departments);

- Research and Innovation: Given the fact that, such project is a national cluster, many universities can participate actively without mare identification to their location on the cluster's geographical perimeter. Furthermore, other researchers are more likely to strengthen the researchers' network, including the following entities:

- $\quad$ Research Institute in Solar Energy and New Energies (IRESEN);

- The International Institute for Water and Sanitation (IEA).

- Vocational training: the Office of Vocational Training and Employment Promotion (OFPPT).

- Professional organizations:

- The Moroccan Cleaner Production Centre (CMPP);

- The Moroccan Association of Drinking Water and Sanitation;

- Association of Water and Energy for All;

- Moroccan Society for Membranes and Desalination;

- As well as professional federations for instance the National Federation of Electricity, Electronics and Renewable Energies (FENELEC).

- Financial institutions: the banks and seed funds, investment and start-up funds as well as innovative companies;

- Support companies: refers to micro-companies conducting maintenance Works of the drinking water network.

The identification of the main stakeholders of the water sector in the Kingdom of Morocco and their duties and functions sheds light on two major points:

Firstly, the Moroccan companies operating in different water sector occupations are specialized in manufacturing water pipelines, importing and selling equipment and Works' achievement. Consequently, they do not carry out activities with technological added value. Yet, the electromechanical equipment industry is mostly the vulnerable link in the field value-added chain of water sector in Morocco.

Then, the lack of coordination, and the versatility of institutional, regional and national stakeholders in Morocco, that results in an overlapping of responsibilities and missions. 


\section{Cluster's Objectives:}

The identification of the objectives of the cluster (Aliouat, 2010), which will be carried out along a period of 5 years, will obviously allow the stakeholders to promote and evaluate the undertaken actions by the end of the first phase of the cluster on a predefined platform.

- Industry strengthening oriented goals:

- Collect and centralize data to identify water and sanitation companies as well as support services companies;

- Propose an "industrial clustering" action amongst small-sized companies to offer a portfolio of a coherent and complementary products and services, enabling them to bid on big projects;

- Establish a "one-stop shop", introducing the Moroccan Offer;

- Organize a determined number of activities and thematic training.

- Research and development oriented goals:

- Initiate a "Multidisciplinary Water Center" within the Cluster Ô, which will be the benchmark for pilot testing innovative projects and a cosmopolitan space that caters for cooperation between researchers and companies;

- Involve collaborative R \& D projects between companies, universities and private research laboratories;

- Achieve a determined number of patents on the first 5 years of the cluster's life.

However, such objectives can be subject to a review at the end of the first phase of the cluster's process in compliance with changes in the cluster's environment, stakeholder needs and the market's demands.

\section{IDENTIFICATION OF THE TYPE OF THE CLUSTER}

The multiplicity of stakeholders and the complexity of the organization of the links between the water sector entities in Morocco are defining the uniqueness of this cluster. The different elements designing the typology of the Cluster Ô have to take into account the specific characteristics of the Water sector in morocco but also it has to match and fulfill its needs.

a. The cluster's organizational form:

Firstly, the choice of the mode of organization of the Cluster Ô must make it possible to reduce the dispersion of the Water sector entities and create the embryo with an integrated local industrial scope. For the same reason we have chosen the State Centered Cluster Model (Markusen, 1996) as a form of organization.

The choice of this model has been made due to the remarkable efforts made by the public and semipublic institutions in Morocco's water sector, in the absence of a joint and solid industrial scope. Thus, an 
Agency for the Promotion of Water Professions should be set up by a consortium of representatives of the National Office of Water and Electricity and the Water department of the Ministry Delegate in Charge of Water, the Ministry of Agriculture and Fisheries, and the basin agencies. As a mission, this agency will have to carry out the project of the Cluster Ô and ensure the financing of innovative collaborative projects.

b. The cluster's governance:

The choice of the mode of governance of the cluster Water is determined through the objectives of the cluster and its form of organization. Thus, territorial governance (Ehlinger \& al., 2007) seems to be the most appropriate for the Water cluster. It is a horizontal mode of governance, which involves all stakeholders in the development of the cluster strategy. The governance of the cluster is not only a bureaucratic structure; it is also an operational system of coordination between the different stakeholders and through the informal networks promoted by the cluster. This "network governance", which is "a hybrid form of market and nonmarket relations aimed at adapting, coordinating and controlling exchanges between autonomous and heterogeneous entities" (Ehlinger \& al., in 2007), develops and extend in the event that the Cluster provides a trust worthy environment and conducive ecosystem supporting the proliferation of collaborative projects, exchanges and innovative initiatives.

However, it is essential to ensure a fair representation of SMEs in the governance structure in order to avoid two speed evolutions.

c. The role of local companies and foreign investments:

The strategic importance of the water sector in Morocco, the dispersion of the market and the national expertise in water professions, are all elements that impose the orientation towards a cluster made essentially of the local companies, whose project is supported by means of a national initiative.

Initiating the core presence of a strong and competitive local industry with high technological added value, is a process that can be slow and unprofitable at first, if compared with hosting Foreign Direct Investment flows. Nevertheless, over time, the development of local businesses in collaboration with local research and development will create an industrial sector strongly rooted in the territory, regardless the costs of the production aspects (Porter, 1990).

\section{d. The location of the Water Cluster:}

The choice of the location of the Cluster Ô depends on several criteria and constraints. Since it is a national cluster, it is not intended to develop a specific territory or region.

Moreover, the stakeholders in the different sectors of the water sector are located in the region that extends from Kenitra to Marrakech. Thus, the historical links of cooperation on a particular territory may not be considered. 
The geographical concentration of seawater desalination projects and the reuse of purified wastewater cannot be considered as an appropriate criterion for choosing the cluster's location either, because of the geographical dispersion of these projects.

As for the development of the cluster around blocks of competences in terms of research and development, neither is a relevant criterion of choice, because several universities are active in research related to water technologies and are located in different regions of the Moroccan territory, for instance the region of Oujda, Fez, Marrakech, Agadir, Rabat, etc.

However, the Agency for the Promotion of Water Professions can be established in Rabat, because all the institutional partners are located there, and because of the proximity of the large drinking water production complex of Bouregreg in Akrach, which provides water services to more than 6 million users. Thus, this choice seems be accurate for the localization of the Cluster Ô.

\section{FINANCIAL SUPPORT AND PUBLIC-PRIVATE PARTNERSHIPS}

The implementation of the cluster's business plan is a crucial step. We define the various financing needs and resources of the cluster, as the following:

- The financing requirements of the Ô Cluster:

- Operating costs;

- Development costs: organization of trainings; Participation in fairs and exhibitions; establishment of common goods (equipments, research facilities, infrastructures and technological means); Launching new products or services; the initiation of the "Multidisciplinary Center for Water" as well as the technology transfer office that will depend on it;

- Unusual costs: resort to consultants or experts.

- The different financing sources:

Undoubtedly, a strategic initiative such as Cluster Ô requires different levels of investment. For instance, the Public-Private Partnership (PPP) is said to be the most appropriate financing booster for large-scale, time-bound projects.

As to the funding of the Cluster Ô, different public entities can be part of it, such as:

- The Ministry of Industry, Trade, Investment and Digital Economy, within the framework of the promotion strategy of clusters;

- The Agency for the Promotion of Water Professions, should be granted a financial contribution, which represents the participation share of the whole consortium of public partners that jointly constitutes it;

- The Public Support Fund for Innovation. 
As well as private capital venture investment funds such as:

- Morocco Numeric Fund;

- Dayam Fund of the SAHAM Group;

- $\quad$ SINDIBAD Fund;

- OCP Innovation Fund for Agriculture Fund;

- Innov Invest fund of the Guarantee Central Fund (Caisse centrale de Garantie);

- Cleantech Maroc Program.

Regarding the self-financing of Cluster Ô, it can come from the following sources:

- Membership dues;

- $\quad$ Selling customized services to members;

- Patents and inventions commercialization, despite the fact that technology transfer programs make, in general, less income than the operation costs of the program itself.

\section{MONitoring}

The success of the cluster depends on the mobilization and involvement of the members. For that, a newly established cluster requires an effective facilitation unit and a well structured governance entity.

\section{a. Establishing the facilitation Unit}

Indeed, the facilitation unit plays a crucial role in the success of the organization of any given cluster, considering the following functions:

- Coordinating the relations between the Agency for the Promotion of Water Professions, the Multidisciplinary Water Center and other partners;

- Conducting various actions to promote non-market relations between the cluster's members and create a trust worthy environment;

- Coordinating collaborative projects for the sake of abridging stakeholder networks;

- $\quad$ Ensuring strategic foresight;

\section{b. Establishing a technology transfer office}

The initiation of a technology transfer office within the cluster amounts to setting up a one-stop shop, which offers quality services to both researchers and industrialists. For Cluster Ô, in an initial phase, and in order to avoid the versatility of organs and units of services, enabling the reduction of the budgets to be allocated; nonetheless, the functions of the office of technology transfer must be the responsibility of the Multidisciplinary Center for Water. Thus, the members of the technology transfer office will be at first the universities that are members of the cluster, as well as the research centers that adopt the same research themes or are active in related fields. 


\section{c. Promoting inter-cluster collaborations}

The Cluster Ô can benefit from these two forms of inter-cluster collaboration:

- Collaboration within a network of national clusters (Solar Cluster, EMC Cluster of Energy Efficiency of Building Materials, Cluster MMC: Morocco Microelectronics Cluster, etc.) with different themes, through workshops or exchange days to share experiences, cross-cutting issues and best practices;

- Establishing partnerships and collaborative projects with foreign clusters having the same theme (ei; the French clusters Eau Milieux Sols, Dream and HYDREOS, the Spanish cluster Agrupación Sectorial del Agua, the Norwegian cluster Water Treatment Alliance, Cluster WASH Mali, etc.), will promote the transfer of technology, the establishment of commercial collaborations, training and the exchange of skills.

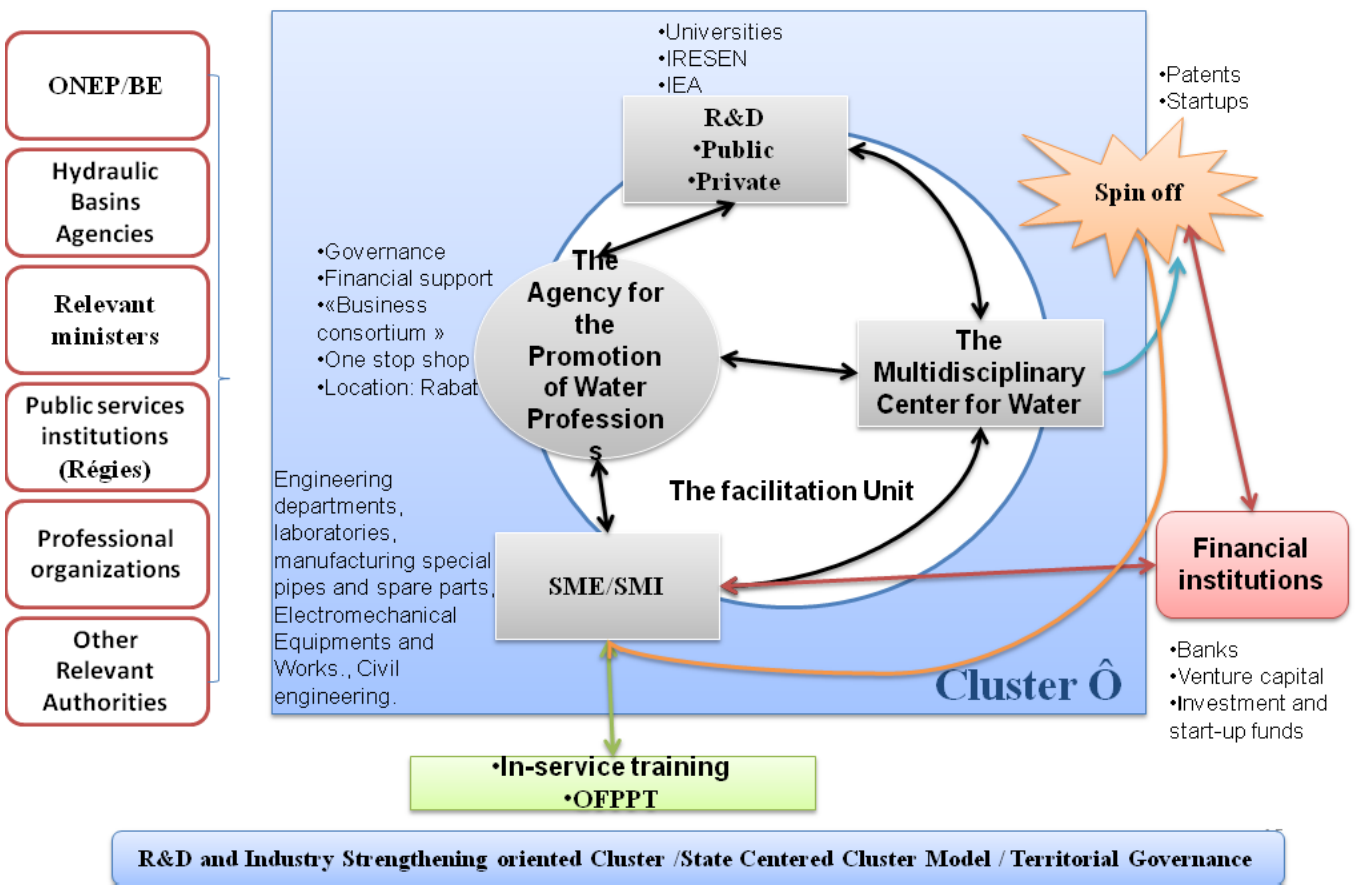

Figure $\mathrm{N}^{\circ} 4$ : The Cluster Ô, organization and ecosystem

Source: Made by the author

\section{EVALUATION OF THE CLUSTER PERFORMANCE AND POST PROJECT SUSTAINABILITY}

a. Evaluation of the cluster performance 
At the end of the first 5 years of Cluster Ô, there will be a performance evaluation. The evaluation of the progress and performance of the cluster can be carried out through the data encrypted on measurable collection and processing criteria relating to the following elements:

- The evolution of the various aspects of the cluster's strategy (communication and marketing, commercial, networking ...);

- The contribution of private investment in the cluster's financial model as an indicator of the viability of the project and the possibility of its empowerment;

- The number of collaborative projects;

- The number of patents and new products and / or services;

- New businesses and startups.

Towards reinforcement and a clear explanation of the analysis's results of the quantitative data collected, it is necessary to collect qualitative information, such as the opinions of cluster members and their perceptions of actions, the level of trust between the actors, and the evolution of the cluster.

The results of this evaluation will make it possible to understand the different challenges faced by the cluster, as well as the identification of the type of projects that require more funding or different funding formulas, and the determination of the cluster's functions that require reinforcement, and to mobilize Actions to improve the cluster's strategic objectives. Finally, yet importantly, the evaluation will enable a better visibility to start the regulatory process and adjust the accompanying measures.

\section{b. The cluster'safter-care and post-project sustainability}

While designing our cluster's model, we have chosen that the public authorities, through dedicated services, would be leading the way, based on a top-down strategy. Their role occurs throughout the life cycle of the cluster. However, the development or atrophy of a cluster depends on several endogenous and exogenous factors whose boundaries become blurred and difficult to distinguish as the cluster develops.

The growth of the cluster depends on the capacity of these stakeholders to act as owners of the project and to take advantage of the mechanism proposed to them by the public authorities and the links between the stakeholders and the density of their interactions which end up making the "collective of actors a collective actor, endowed with an overall project" (Bossard-Préchoux, V. \& Bréchet, J P. 2009).

Once the cluster is created, a chain reaction would be triggered, feeding on a multitude of causes and effects, the evolution of which is closely linked to the socio-economic-cultural environment of the cluster, and challenges facing the cluster. This is how the identity and the future of the cluster are tailored to act as unique entity and a singular experience. 


\section{CONCLUSION}

The role of governments in the development of economies is no longer subject to the old binary distinction: laissez-faire or interventionism. Porter (1998) has shed light on the need for balanced action of governments based on the complementarities between social policy and economic policy. This is to ensure " A minimalist government role in some areas (e.g., trade barriers, pricing) and an active role in others (e.g., ensuring vigorous competition, providing high-quality education and training)" (Porter, 1998).

The government's action to promote an ecosystem conducive to economic and social development is reflected in the policies for setting up clusters. These are organized efforts to improve the growth and competitiveness of a region through the support of its enterprises through the development of an ecosystem where all the players concerned find their places. It is a new form of partnership that is developing around the world (Solvell, Lindqvist, Ketels, 2003).

Finally yet importantly, our proposal for establishing the Water Cluster is not final. Thus, we highly recommend the involvement of representatives from all stakeholders in the water sector to jointly reflect their ideas and make their own contributions in a participatory approach.

\section{Our Contribution}

The design of a Cluster model dedicated to the development of the water industry in Morocco, in the light of a complex theoretical framework and field researches. The Cluster Ô aims to bring all the water sector stakeholders together in order to develop a national industry that is competitive and solid and can be exported.

\section{The limits of this research}

As we explained at the beginning of this paper, the empirical research we have carried out is of an exploratory nature, so the results presented above are rather preliminary and need to be corroborated by future more in-depth work.

Also, in order to constitute our analysis we have used a multitude of theories, which can give an impression of uncertainty. However, this choice was imposed by the complexity of the research fields (clusters and water industry) and allowed us to issue a rich proposal that can answer our problematic.

\section{REFERENCES}

[1] Abrams, I. Leung, G. Stevens, A. 2009 « How are U.S. Technology Transfer Offices Tasked and Motivated- Is It All about the Money? » Research Management Review, Volume 17, Issue 1. https://www.bu.edu/otd/files/2011/02/How-are-US-Tech.-Transfer-Offices-Tasked-andMotivated.pdf last consulted 23/06/2016.

[2] Albors, O.J. Blanca de-Miguel, B. Hervas, L.J. Hidalgo, A. 2012 « The role of a firm's absorptive capacity and the technology transfer process in clusters: How effective are technology centres in low-tech clusters? », archives de l'Université Polytechnique de Madrid. http://oa.upm.es/15701/1/INVE_MEM_2012_130147.pdf last consulted 21/06/2016.

[3] Aliouat B., 2010, «Les pôles de compétitivité : gouvernance et performance des réseaux d'innovation », Edition Lavoisier, Paris. 
[4] Amine R, 2017 «Les clusters au Maroc : vers l'émergence d'une nouvelle politique industrielle territoriale ». Marché et organisations $\mathrm{n}^{\circ} 26$, Edition L'Harmattan.

[5] Asheim, B., Cooke, P. \& Martin, R. (eds.) (2006). Clusters and Regional Development: Critical Reflections and Explorations, London and New York: Routledge./ Torre, A. (2006). Clusters et systemes locaux d'innovation: Retour critique sur les hypotheses naturalistes de transmission des connaissances a l'aide des categories de l'economie de la proximite. Region et Developpement, pp. 15-43.

[6] Becattini, G., 1989, Sectors and/or Districts: Some Remarks on the Conceptual Foundations of Industrial Economics.

[7] Champagne C., « une analyse marshallienne des districts italiens », IUTA, département GEA, Université de Lyon 1, 2008.

[8] Di Méo, G., 1988, Géographie sociale et territoire, in Moine, A., Janvier 2005, « Le territoire comme un système complexe ; Des outils pour l'aménagement et la géographie ». Septièmes Rencontres de théo Quant.

[9] Eaton J., Kortum S. (1996) Trade in ideas Patenting and productivity in the OECD. Journal of International Economics, 40(34), pp. 251-278. In Glachant, M. Dussaux, D. Ménière, Y. Dechezleprêtre, A. (2013).

[10] Ellul, J. (1964). The technological society (J. Wilkinson, Trans.). New York: Alfred A. Knopf. http://www.ratical.org/ratville/AoS/TheTechnologicalSociety.pdf last consulted 07-06-2016.

[11] Drucker-Godard C., Ehlinger S. et Grenier C. (2007), "Validité et fiabilité de la recherche", dans Méthodes de recherche en management, sous la direction de Thiétart R. A. (coord.), Dunod, Paris, p In Anne BERTHINIER PONCET, 2006 «Gouvernance et innovation dans les clusters à la française Une approche par les pratiques institutionnelles » https://halshs.archives-ouvertes.fr/tel-00770164/document last consulted 12/06/2016

[12] Fujita, M., \& Thisse, J.-F. «Economie géographique, problèmes anciens et nouvelles perspectives». Anales d'économie et de statistique ( $\left.\mathrm{n}^{\circ} 45\right),(1997)$.

[13] GTZ, 2009 « Potentiel de réutilisation des eaux usées épurées au Maroc, étude du secrétariat d'Etat à l'eau et l'environnement en cours ». http://www.agiremaroc.org/fileadmin/user_files/pdf/presentation_agadir/lundi/2\%20situation\%20et\%20perspectives\%20de\%20r\%C3\%A9utilis ation/MarkHILLAIRET-potentieldeREUauMaroc.pdf last consulted 05/09/16.

[14] Glachant, M. Dussaux, D. Ménière, Y. Dechezleprêtre, A. (2013) « Promouvoir le transfert international des technologies à basse émission carbone : constats et solutions possibles », Commissariat général à la stratégie et à la prospective, MINES ParisTech. http://www.strategie.gouv.fr/sites/strategie.gouv.fr/files/archives/Promouvoir_le_transfert_des_techs_bas_carbone12-11-2013.pdf last consulted 03/04/2016.

[15] Hoover E. M., « Location Theory and the Shoe and Leather Industries» The Economic Journal, Vol. 47, No. $188,1937$.

[16] International Bank for Reconstruction and Development / World Bank "Management of Water Scarcity in Urban Areas in Morocco "2017

[17] Krugman P., « Scale Economies, Product Differentiation, and the Pattern of trade », American Economic Review, 70.1980.

[18] Markusen, A. (1996), Sticky places in slippery space: a typology of industrial districts, Economic Geography 72, 293-313 cité dans Catalin Boja, "Clusters Models, Factors and Characteristics", International Journal of Economic Practices and Theories, Vol. 1, No. 1, 2011Marshall A., «Principes d'Economie Politique » traduit par F. Sauvraire -Jourdan, Gordon \& Breach (1971), Paris-Londres-New York, 12 volumes, 1920.

[19] Ministère de l'Energie, des Mines, de l'Eau et de l'Environnement, département de l'Eau. 2013 « Stratégie Nationale de l'Eau en matière de protection et de développement de l'offre : Réutilisation des eaux usées épurées ».

[20] Ministère de l'Energie, des Mines, de l'Eau et de l'Environnement, chargé de l'Eau et de l'Environnement « Rapport de Présentation de Plan d'Action »- Groupe de Travail nº 4 : Déminéralisation des eaux saumâtres. Unité de Gestion de Projets chargé de la mise en œuvre de la Stratégie Nationale de l'Eau -Département de l'Eau- Secrétariat d'Etat auprès du Ministère de l'Energie, des Mines, de l'Eau et de l'Environnement, chargé de l'Eau et de l'Environnement. http://dessalementunisie.emonsite.com/pages/sous-partie/1-4-distillation-par-detentes-successives-ou-multistages-flash-msf.html , last consulted, Novembre 2014.

[21] Moine, A., 2005, «Le territoire comme un système complexe ; Des outils pour l'aménagement et la géographie ». Septièmes Rencontres de théo Quant.

[22] Office National de l'Electricité et de l'Eau Potable - Branche Eau, (ONEE/BE) 2013 a, « Situation des ressources en eau et du remplissage des barrages durant l'année hydrologique 2011-2012». 
[23] Office National de l'Electricité et de l'Eau Potable - Branche Eau, Direction de la Planification, (ONEE/BE), 2013b, « Secteur de l'eau au Maroc et stratégie de l'ONEE-Branche eau ».

[24] Office Chérifien des Phosphates, 2014 «Programme de dessalement d'eau de mer : Une solution de pointe pour plus d'éco efficacité »http://www.ocpgroup.ma/sites/default/files/alldocs/Programme_de_dessalement_de\%20leau_de_mer.pdf last consulted 07/09/2016

[25] Organisation des Nations Unies, Commission économique pour l'Afrique, 2015 «Industrie et économie verte en Afrique du Nord Enjeux, pratiques et enseignements ».

[26] Oldenburg, R. «The Great Good Place. New York» Marlowe \& Company, 1991, dans Suire R. \& Vicente J., « Récentes enseignements de la théorie des réseaux en faveur de la politique et du management des clusters. », Centre de Recherche en Economie et Management, working paper. Mai 2014.

[27] PNUE-PAM, 2009 «Etat de l'environnement et du développement en méditerranée », http://www.actuenvironnement.com/ae/news/dessalement_espagne_eau_potable_barcelone_secheresse_8174.php4 consulté le 02-01-2015

[28] Porter M. 1990, The Competitive advantage of nations, The Free Press, New York.

[29] Porter M., 1997 «The Adam Smith Address: Location, Clusters, and the "New" Microeconomics of Competition», the 39th Annual Meeting of NABE, New Orleans, LA, September 14-17.

[30] PORTER M. 2004, Diamond of competitive advantage, New York.

[31] Raffestin,C., «Ecogenèse territoriale et territorialité » in Espaces, jeux et enjeux, (F.Auriac et ER Brunet, dir.), Ed. Fayard, Paris. 173-175.

[32] Rapport sur la situation des ressources en eau et du remplissage des barrages durant l'année hydrologique 2011-2012-- Office National de l'Electricité et de l'Eau Potable - Branche Eau

[33] Rosenfeild S., 1997, « Bringing business clusters into the mainstream of economic development », European Planning Studies.

[34] Schumpeter, J.A. 1934, «The Theory of Economic Development», Oxford University Press, Oxford.

[35] Solvell O., Lindqvist G., Ketels C., 2003 «The Cluster Initiative Greenbook”.

[36] Suire R. \& Vicente J., «Récentes enseignements de la théorie des réseaux en faveur de la politique et du management des clusters. », Centre de Recherche en Economie et Management, working paper. Mai 2014

[37] Torre, A. «On the role played by temporary geographical proximity in knowledge transfer», Regional Studies 42, 2008, dans Suire R. \& Vicente J., «Récentes enseignements de la théorie des réseaux en faveur de la politique et du management des clusters. », Centre de Recherche en Economie et Management, working paper. Mai 2014.

[38] Weber A., «Theory of the location of industries» Trans. Freidrich, C.J.Chicago : University of Chicago Press. 1929. 